\title{
Major Onion (Allium cepa L.) Production Challenges in Ethiopia: A Review
}

\author{
Muluneh Bekele Etana \\ Department of Horticulture, College of Agriculture and Veterinary Science, Ambo University, Ambo, Ethiopia \\ Mosissa Chewaka Aga \\ Department of Horticulture, College of Agriculture and Veterinary Science, Ambo University, Ambo, Ethiopia \\ Bikila Ollika Fufa \\ Department of Horticulture, College of Agriculture and Veterinary Science, Ambo University, Ambo, Ethiopia
}

\begin{abstract}
Onion is an important vegetable crop, which has produced worldwide including of Ethiopia for its daily uses and economic benefits. The beginning of its production was traced back to the introduction of planting material from Sudanese and recently it has produced intensively and by now smallholder farmers in most parts of the country produces the crop. Despite to its lower productivity, which brings below the world average, onion is becoming as the sources of livelihood for many peoples who have engaged in the production and trading. The main reason for this lower productivity of the crop is most probably due to lack of improved onion cultivars, inappropriate agronomic practices and a little-given attention to the crop production. Hence, most of the grower uses the planting material that has obtained from their local markets, from semi-formal seed producers and from imported seeds (not tested for its quality) which are inferior in yield, easily susceptible to diseases and insect pests and none adapted to wider agro-ecologies. Currently, therefore, the absence of an authorized body that produces and distributes the improved onion seed materials at the country level is the main challenges of the sector. However, the area under cultivation is increasing from time to time both under rain feed and irrigation conditions due to its economic profitability. Also, an inevitable yield and yield component improvement activities including of plant nutrient management, crop water requirements and scheduling programs, plant population densities, and disease and insect pest control systems were identified. Therefore, this paper mainly to review on the major onion production challenges in the country.
\end{abstract}

Keywords: Allium cepa L., Challenges, Ethiopia, Onion, Production

DOI: $10.7176 / \mathrm{FSQM} / 86-01$

Publication date: April $30^{\text {th }} 2019$

\section{Introduction}

Onion (Allium cepa L.) belongs to the genus Allium of the family Alliaceae which was believed to be originated in southwestern Asia, being the centre of domestication and variability, from where it was spread first across the world and has been cultivated for over 4700 years as annuals for bulb production purposes (Brewster, 2008). The introduction of onion crop to Africa in general and in Ethiopia, in particular, was not well known. However, it has suggested that as introduced by foreigners recently and by now produced widely in many parts of the country than the traditionally grown shallot (Adgo, 2008). Currently, Allium species have adapted to several ecological niches and Onion is cultivated around the world for its important benefits (Brewster, 2008).

The onion is recognized as one of the most important vegetable crops that cultivated throughout the world since its introduction to the worlds. It has grown mainly as a food source and used as cousins and value addition for different dishes. In Ethiopia, the consumption of the crop is very important in the food seasoning and in daily stews as well as in different vegetable food preparation uses. Also, the chemical flavonoids, anthocyanins, fructooligosaccharides and organo-sulphur compounds found in the onion is considered as medicinal and health benefits to fight different diseases including cancer, heart and diabetic diseases (Goldman, 2011). Due to this considerable benefits, the onion production is become increasing in different agro-ecologies of the country in small-scale production systems being as one component of commercialization for rural and urban peoples as sources of daily income. However, its production status is not well-developed and organized despite to all the available opportunities. This might be due to the lack of improved cultivars that are well adapted to different agro-ecologies and infestation of diseases and insect pests that take the lion share of low productivity. In addition, a little attention to the production and non-organized marketing systems of the crop are contributing to its passive production progresses despite the ever-rising demands from time to time over almost all the country. Due to the fact of onion is an important vegetable crop in Ethiopia daily diet and people's livelihood. Therefore, this paper is aimed to review on the major challenges of onion production in Ethiopia. 


\section{Literature Review}

\subsection{Onion (Allium cepa L.) Production in Ethiopia}

In Ethiopia, the agricultural sector accounts for 55\% to the Gross Domestic Product and provides $85 \%$ of employment (CSA, 2009). The country has favorable conditions for the production of several crops specious. The wide range of altitude gives it a wide range of agro ecological diversity ranging from humid tropics to alpine climates, where most vegetable crops can be successfully grown. Onion was introduced to the agricultural community of Ethiopia in the early 1970s when foreigners brought it in. Though shallots are traditional crop in Ethiopia, onions are becoming more widely grown in recent years. Currently, onion is one of the most important vegetable and spice crop in Ethiopia and mainly produced as a cash sources for the farmers.

Onion is a high-value bulb crop that has produced by smallholder farmers and commercial growers for both local and export markets in Ethiopia (Aklilu, 1994). It ranked the second in production of all vegetable crops next to Tomato, which has been concentrated in the central rift valley of the country particularly in the upper Awash and Lake Ziway areas (Bossie, 2009). Onion is currently becoming a popular crop relatively despite to its recent introduction to the country because of its yield potential per unit areas, the ease of propagation method both by seed and bulb method, and the presence of high domestic and export markets (Asfaw and Eshetu, 2015). Hence, Nikus and Mulugeta, (2010) also elaborated the area under onion production is an increasing rate from time to time mainly due to the merit of production and ease of marketing purposes. This crop can be cultivated twice per year both under the irrigation and rain feed conditions in different parts of the country (Belay et al., 2015). However, the production and productivity of the crop are far below $(10.02 \mathrm{t} / \mathrm{ha})$ the world average $(19.7 \mathrm{t} / \mathrm{ha}) \mathrm{despite}$ to its year-round production scenarios (FAO 2012). This low yield results indicate that the presence of a huge gap in production and productivity at the country because of the absence of improved cultivars, application of inappropriate agronomic practices and limited attention/awareness on the benefits of intensive production. Within the context of efforts to achieve safe, sound and sustainable production of vegetables, identification of risk sources plays a crucial role (Kumilachew et al., 2014).

\subsection{Onion Production Challenges in Ethiopia}

Despite the immense merits of onion to farmers, their production has been constrained by a myriad of biotic and abiotic factors as well as institutional. The majority of the sample producers indicate disease and pests attack, weeds, shortage of quality seed, lack of pesticide and lack of irrigation water/pump for irrigation as major constraints of onion production in the area. Similarly, a survey in rift valley (major onion growing area) confirmed that pests and diseases, coupled with a low level of improved agricultural technology, recurrent droughts, and decreases in soil fertility levels are some of the major contributors to the low and unstable crop yields in Ethiopia (Eshetu et al, 2006).

According to Dinham, (2003) vegetables, generally, are susceptible to a wide range of pests and diseases, and require intensive pest management. According to the research report, about $77.78 \%$ of the respondent's ranked insect attack is the most important production problem followed by disease attack and lack of pesticide/poor management, $75 \%$ and $70 \%$, respectively. In addition to disease and pest problems, the results from the key informants and farmers group discussions stress the critical importance of postharvest losses which occur due to the perishable nature of onion and lack of appropriate postharvest handling practices and processing technologies. The high incidence of insect pest and diseases infestation further accentuates high pre-harvest and postharvest losses.

\subsubsection{Plant population density management problems}

The improved agronomic management is an important practice to reduce the yield gap and to enhance the food security within an area and among farming households (Fanadzo et al., 2011; Kihara et al., 2015). A plant population density is one of the important agronomic factors which can limit the onion production and productivity in Ethiopia (Yemane, 2013). According to Winch (2006) report, a plant which has been grown too close together are competing for sunlight, essential nutrients, water, and air that leads to producing small bulb with a low quality whereas a plant which has grown too far apart produces vigor individual plant but low yield per given areas. Hence different onion varieties have responded differently to various plant spacing's (Awas, 2010).

According to Belay (2015) research finding, Adama red onion variety which has been evaluated under fiche condition of Ethiopia has responded to different intra row spacing on different bulb yield parameters. Awas (2010) also added a similar report that three onion varieties, Bombay red, Adama red and Nasika red, responded differently to intra-row spacing on yield and yield components at Adami Tulu. The results showed that the presence of this competition among plants for the same resources is due the need of plants to get their maximum growth and developments to attain their potential yields. Therefore, the identification of this yield-limiting factor due to population density is very important for onion against to lower yield trends in the country.

\subsubsection{Fertilizer management problems}

Plant nutrient management improvement has an important role in normal plant growth and developments especially for the vegetative plant parts to give optimum yields. The addition of manure, compost and/ or inorganic 
fertilizer improves the onion production and hence benefits the producers (zeleke and derso, 2015). According to Assefa et al. (2015) finding, using the optimum amount of fertilizer nutrients substantially increases the productivity of onion bulbs beside to using of improved cultivars. Because of Onion is one of the heavy feeders vegetable crop, it requires more mineral fertilizers than other vegetables for a bulb and shot growth (Yohannes et al., 2013). According to Simon et al. (2015) report, three onion varieties (Adama Red, Bombe Red, and Nafis) have been tested at humbo, wolaita zone; Ethiopia was responded to different application of nitrogen and phosphorous fertilizer rates. The finding revealed that the size and onion bulb yield has increased as the level of nitrogen and phosphorous were increased which implies as the optimum nutrient management has a positive contribution to yield improvement of onion production and productivity especially for those areas where a nutrient deficiency is critical. Yohanis et al. (2013) also reported a similar finding on the effects of combined application of nitrogen and farmyard manure which has increased the onion bulb yield at Jimma environmental condition.

Furthermore, the effects of nitrogen and phosphorous on onion yield and yield components were studied on the vertisol of Shewa Robit, Northeast Ethiopia, has been responded to a different rate of the fertilizers and recommended based on the optimum yield obtained (Abdisa et al., 2011). According to this research output, the application of nitrogen and phosphorus fertilizer showed a significant response on a fresh bulb yield, dry bulb yield, and total dry biomass and on harvesting index of onion as compared to the non applied treatments. Generally, all the results of different nutrient management practices have been shown that the onion yield production and productivity can be maximized by applying different plant nutrient management systems for the specified soil types at specific locations. Even though, the rate of fertilizers should be determined based on the soil type of the areas, $200 \mathrm{~kg} / \mathrm{ha}$ DAP before transplanting by incorporating with soil and $100 \mathrm{~kg} / \mathrm{ha}$ of urea after 45 days of transplanting has been advised as it is sufficient in most parts of the country (Zeleke and Derso, 2015).

\subsubsection{Crop water requirement problems}

Water availability is the main limiting factor of crop productivity than all of the rests due to its paramount importance for normal plant growth and developments. Hence, due to its shallow root system and needs frequent irrigation water after a short interval, onion is susceptible to water stress as compared to other crops (Fitsum et al., 2016). Knowing a number of water requirements of onion based on the specific area is basically important to produce the optimum onion yields. Bossie (2009) elaborated that, knowing of the water requirement and the coefficient values of the crop can help to accurately plan and manage the irrigation water for onion production at different locations even an area where a water shortage is very critical. Therefore, assuming of high irrigation frequency and better scheduling method may be expected to increase the applied fertilizer use efficiency, reduces leaching effects and to improve onion yields by increasing bulb sizes (Serra and Currah, 2002). Currently, from the recommended onion cultivars by Melkassa agricultural research center, Bombay red is the most widely grown onion variety under irrigation water in the country due to its higher bulb yield, earliness and susceptible to the rotting disease under a rain-fed condition at maturity stage (Nikus and Mulugeta, 2013). As a result, knowing of the individual crop water requirements help to produce more than two times per annum to ensure the year-round production of onion in order to get a high return as well as to reduce the susceptibility of the crop to various diseases and insect pests.

\subsubsection{Disease and insect pest problems}

Disease and insect pests are the most important yield reducing factor for different vegetable crop production systems including of onion. Onion is the crop that can be easily susceptible to diverse biotic and abiotic stresses. Diverse types of pathogens are affecting the crop by causing diverse diseases based on the available conducive environmental interactions with susceptible cultivars. As a result, several farmers in Gojjam zone of Amhara region has shifted to shallot rather than onion production due to disease severity and other observed problems in the area (Maru, 2014). The same is true for other parts of the country which take the lion share of onion yield reduction. Some diseases were identified as causing huge loss unless treated based on their types and causes of diseases. Based on this, different fungal pathogens are attacking the crop by causing the economic losses.

Botrytis leaf blight or neck rot is one of fungal disease which affects only onion in cool climate areas on worldwide. The disease is primarily the storage disease which may infect by spores blown from infected onion debris and improperly disposed of cull piles (Eshetu, 2015). This disease identified in Ethiopia and the management option has been set which mostly overcome by preventing the disease introduction to the field site and chemical control methods like different types of fungicide have been recommended to reduce the pressure it causes to the yield and productivity of the crop plant. Fusarium basal rots (fusarium oxysporum) also identified as another fungal disease-causing pathogen of onion in Ethiopia. The yield losses by basal rot can be more than $50 \%$ which can effects by attacking of the cloves and seedlings, causing pre and post-emergence damping off, root rot of older plants, and steam plate discoloration and basal rot of bulbs in the field and storage (zeleke and derso, 2015). The disease can be controlled by preventing the disease occurrences and by applying of fungicide chemical. Vegetables, generally, are susceptible to a wide range of pests and diseases, and require intensive pest management.

Similarly, Thrips is one of the challenging insect pests of onion which mainly affects the leaf parts of the plant that reduces the yield and productivity of the crop. Currently, however, different research work has been 
undertaking by focusing on the identification of different disease and insect pests and their mitigation strategies to overcome the observed problems and to boost the production and productivity of the crop in the country (Eshetu, 2015).

\subsubsection{Postharvest handling problem}

Postharvest losses which occur due to the perishable nature of onion and lack of appropriate postharvest handling practices and processing technologies are common in onion production which is an important production constrains causing yield reduction. According to researcher's major causes are mainly connected to financial, managerial and technical limitations in harvesting techniques, storage and cooling facilities in difficult climatic conditions, infrastructure, packaging and marketing systems (Gebru et al., 2015). Similarly, some researchers reported the most common causes of postharvest losses such as lack of sorting to eliminate defects before storage and the use of inadequate packaging materials, rough handling and inadequate cooling and temperature maintenance (Kitinoja et al., 2002).

\subsubsection{Marketing problem}

The socio-economic attributes of the farming families related to their families and farms are generally considered important in the level of receptivity of innovations and boosting farm productivity (Farooq et al, 2006). The major reason for the increased yield of onion is farmers' awareness of the benefits of production and marketing of vegetables (onion) and that farmers have given more attention to vegetable production like onion due to its comparative advantages to generate a higher income within short period of time. This might also be the reason why some farmers rent in land to expand onion.

Farmers grow onion crop for the purpose of selling to get cash. However, onion production is seriously affected by price fluctuation every year. The middlemen were the major collectors of onion produce from each grower with low price.

\section{Summary and Conclusions}

Onion is among of the most important vegetable crops grown around the world mainly for its requirements in the daily consumption and for its health benefits for human beings. Due to this fact, its production is concentrated into the three world top producers (China, India, and the USA) for both their daily consumption and/or for export markets purposes. In Ethiopia, its production history is stretched back to 1970's when foreigners brought the planting material into the country from Sudan and since its intensive production has been started. Later on, the improved cultivars were released by Melkassa agricultural research center which has been incorporated into the farming system of the country. Even though these improved varieties were introduced, different smallholder growers are still using the planting material which has been obtained from their local markets and informally imported seed which is not checked and non-resistant to different diseases and insect pests. Moreover, lack of appropriate agronomic practices, the absence of irrigation water scheduling and a little attention given to the crop production makes the country below average producers even in Africa. More importantly, lack of improved varieties and absence of any responsible agents who produces and distributes the improved seed materials to the growers were the main bottleneck problems at the country level. However, nowadays, due to the presence of awareness for its nutritional and health benefit as well as for its economic requirements, different encouraged practices like an adaptation of different cultivars to the various agro-ecologies, uses of an appropriate agronomic management, improvements of crop water requirements, plant fertilizer requirement and rate optimization, disease and insect pest identification and its mitigation activities are underway by various research centers and higher learning institutes.

As a general, the government should have to give a due attention to onion production to get all the possible advantages from of the crop. Also, research centers and higher learning institutes should have adapted to the growers with its full packages and should strive to develop appropriate cultivars for different agro-ecologies of the country. To full fill the observed gap for the future it needs a focus on the adaptation of improved varieties to the remaining potential areas, fertilizer nutrient management which includes the micro and macro nutrients also needs a great attention to produce the maximum yield from the crop. The water use efficiency improvement further needs a critical attention to overcome the problem regarding crop in the country.

\section{Conflict of interest}

Regarding the publication of this manuscript, there is no any conflict of interest.

\section{Acknowledgements}

We would heartedly like to thank and praise the Lord Almighty God in giving us strength and wellbeing to successfully complete the study. We also want to thanks for all Ambo University horticulture department staff for all their help and moral support. Finally, all the reference materials used in this paper are dully acknowledged. 


\section{References}

1. Abdisa Y, T Tekalign and LM Pant, 2011. Growth, bulb yield and quality of onion (Allium cepa L.) as influenced by nitrogen and phosphorus fertilization on vertisol I. growth attributes, biomass production, and bulb yield. African J Agric Res, 6: 3252-3258.

2. Adgo TM, 2008. Farmers' evaluation and adoption of improved onion production package in Fogera District, South Gondar, Ethiopia (Doctoral dissertation, Haramaya University).

3. Aklilu S, 1994. Onion research \& production in Ethiopia. In International Symposium on Edible Alliaceae 433, pp: 95-98.

4. Assefa AG, SH Mesgina and YW Abriha, 2015. Effect of inorganic and organic fertilizers on the growth and yield of garlic crop (Allium sativum L.) in Northern Ethiopia. J Agric Sci, 7:80.

5. Awas G, T Abdisa, K Tolesa and A Chali, 2010. Effect of intra-row spacing on a yield of three onion (Allium cepa L.) varieties at Adami Tulu agricultural research center (mid-rift valley of Ethiopia). J Hort For, 2: 711 .

6. Belay S, D Mideksa, S Gebrezgiabher and W Seifu, 2015 Yield components of adama red onion (Allium cepa L.) cultivar as affected by intra-row spacing under irrigation in fiche condition. Department of Horticulture, College of Veterinary Medicine and Agriculture, Addis Ababa University, Fiche, Ethiopia

7. Bossie M, K Tilahun and T Hordofa, 2009. Crop coefficient and evapotranspiration of onion at Awash Melkasa, Central Rift Valley of Ethiopia. Irrig Drain Systems, 23: 1-10.

8. Brewster JL, 2008. Onions and other vegetable (No 15). CABI. Inter J Agri Biosci, 2017, 6(5): 265-271.

9. Fanadzo M, C Chiduza, PNS Mnkeni, Van der I Stoep and J Stevens, 2010. Crop production management practices as a cause for low water productivity at Zanyokwe Irrigation Scheme. Water SA, 36: 27-36.

10. FAO, 2012. Crop production data: http:/www.faostat. fao.org, Accessed, September 17, 2013.).

11. FAO, 2012. Major Food and Agricultural Commodities and Producers -Countries by Commodity". Food and Agriculture Organization of the United Nations Www.fao.org. Retrieved 2012-05-18.

12. Fitsum, G, K Woldetsadik and Y Alemayehu, 2016. Effect of Irrigation Depth and Nitrogen Levels on Growth and Bulb Yield of Onion (Allium cepa L.) at Algae, Central Rift Valley of Ethiopia.

13. Goldman IL, 2011. Molecular breeding of healthy vegetables. EMBO Rep 12: 96-102.

14. Central Statistical Agency (CSA), 2009. "Crop and livestock product utilization." Vol. VII . Agricultural Sample Enumeration Survey. Addis Ababa, Ethiopia.

15. Kahsay Y, F Belay \& A Embaye, 2013 Enhancing onion production and productivity through the introduction of seed production techniques in the central zone of Tigray, Ethiopia. Academia J Agric Res, 4: 188-192.

16. Kihara J, LD Tamene, P Massawe \& M Bekunda, 2015. Agronomic survey to assess crop yield, controlling factors \& management implications: a case-study of Babati in northern Tanzania. Nutrient Cycling in Agroecosystems, 102: 5-16.

17. Gebru H, Belew D (2015) Extent, Causes and Reduction Strategies of Postharvest Losses of Fresh Fruits and Vegetables - A Review. Journal of Biology, Agriculture and Healthcare, 5(5).

18. Kitinoja L, Kader AA (2002) Small-Scale Postharvest Handling Practices: A Manual for Horticultural Crops ( $4^{\text {th }}$ edn) woodland: University of California, Davis.

19. Manna D, 2014. Growth, yield and bulb quality of onion (Allium cepa L.) in response to foliar application of boron and zinc. SAARC J Agric, 11: 149-153.

20. Nikus $\mathrm{O}$ and F Mulugeta, 2010. Onion seed production techniques. A manual for extension agents and seed producers, Asella, Ethiopia p1.

21. Serra ADB and L Currah, 2002. Agronomy of Onions. Allium crop: recent advances, pp: 187.

22. Simon T, M Tora, A Shumbulo and S Urkato, 2015. The effect of variety, nitrogen and phosphorus fertilization on growth and bulb yield of onion (Allium cepa L.) at Wolaita, Southern Ethiopia. J Biol, Agric Healthcare, 4: 90-92.

23. Winch, T, 2006. Growing Food (pp. 1-103). Springer

24. Yohannes KW, D Belew and A Debela, 2013. Effect of farmyard manure and nitrogen fertilizer rates on growth, yield and yield components of onion at Jimma, Southwest Ethiopia. Asian J Plant Sci, 12: 228.

25. Zeleke A and E Derso, 2015. Production and management of major vegetable crops in Ethiopia. pp: 32-51. Ethiopian Institute of Agricultural Research. Addis Abeba, Ethiopia.

26. Esheteu Bekele, E., Azerefegne, F and Abate, T. (2006). Facilitating the Implementation and Adoption of Integrated Pest Management (IPM) in Ethiopia. Planning Workshop, 13-15 October 2003, Melkassa Agricultural Research Center, EARO. Jointly organized by the Association for Advancement of IPM (ASAI) and the Ethiopian Agricultural Research Organization (EARO). DCG, Miljøhuset, Oslo.

27. Farooq U, Sharif M, Erenstein O (2006). "Adoption of Zero Tillage in the Rice- Wheat, Zone of Irrigated Punjab, Pakistan", Rice-Wheat Consortium for the Indo-Gangetic Plains, CG Block, NASC Complex, DPS Marg, Pusa Campus, New Delhi-110012, India. 
28. Kumilachew A., Mengistu K., and Fekadu G (2014). Risks in vegetables production from the perspective of smallholder armers: The case of Kombolcha Woreda, Oromia region, Ethiopia. Agriculture, Forestry and Fisheries 2014; 3(6-1): 1-5 